Volume 2 Nomor 1, Mei 2021: h. 78 - 92

P-ISSN: 2722-4465, E-ISSN: 2746-8151

Lisensi Creative Commons Atribusi-NonCommercial 4.0 Internasional

\title{
Hak Pakai Atas Tanah Hak Milik dan Penyelesaian Sengketa
}

\author{
Suryani Sappe ${ }^{1}$, Adonia Ivone Latturete ${ }^{2}$, Novyta Uktolseja ${ }^{3}$
}

1, Pascasarjana Ilmu Hukum Universitas Pattimura, Ambon, Indonesia.

2, 3, Fakultas Hukum Universitas Pattimura, Ambon, Indonesia

E-mail: suryanisappe1@gmail.com

\begin{tabular}{l}
\multicolumn{1}{c}{ Dikirim: $03 / 02 / 2021$} \\
\hline Info Artikel \\
\hline Keywords: \\
Land Use Rights; Land \\
Ownership Rights; Dispute \\
resolution. \\
\\
Kata Kunci: \\
Mak Pakai Tanah; Hak \\
Sengketa.
\end{tabular}

Direvisi: 09/04/2021

Dipublikasi: 31/05/2021

\begin{abstract}
The process of the occurrence of use rights over land is based on statutory regulations and government regulations to prevent misuse of the administration process. However, in this era of increasingly modern life, there are many disputes relating to control and use of land for public, individual and private interests. The right to use is not at all a new land rights institution, but it is less well known than the ownership rights, land use rights, or building use rights, for that it requires a correct understanding of the right to use in order to use it responsibly. The purpose of this paper is to study and analyze the arrangements for use rights over land with ownership rights and to study and analyze the process of settling usufructuary disputes over land with ownership rights. The method used in this research is the normative juridical method using the statute approach and the conceptual approach, and the case approach is then studied and used as material for descriptive analysis in order to obtain answers to the problems that occur. The results of the research show that the regulation of use rights over land with ownership rights is very important because, when the right to use stands, buildings or objects become assets of the recipient of the right to use. So when the right of use expires or is canceled it will have a legal effect on the objects on $i t$, thus it is hoped that there must be regulations governing objects or buildings that are included in the relinquishment of use rights even though there is an agreement made by the parties.
\end{abstract}

\begin{tabular}{l}
\hline Abstrak \\
\hline Proses terjadinya hak pakai atas tanah beradasarkan aturan- \\
aturan perundang-undangan maupun peraturan pemerintah \\
untuk mencegah penyalahgunaan proses jalannya administrasi. \\
Namun dalam era kehidupan yang semakin modern ini, \\
terdapat banyak sengketa yang terjadi berkaitan dengan \\
penguasaan dan penggunaan tanah baik untuk kepentingan \\
umum, kepentingan individu, maupun pihak swasta. Hak \\
pakai sama sekali bukan lembaga hak atas tanah yang baru, \\
namun kurang dikenal jika dibandingkan dengan hak milik, \\
hak guna usaha, atau hak guna bangunan, untuk itu diperlukan \\
pemahaman yang benar mengenai hak pakai agar dapat \\
menggunakannya secara bertanggungjawab. Tujuan penulisan \\
ini untuk mengkaji dan menganalisis pengaturan hak pakai atas \\
tanah hak milik dan mengkaji dan menganalisis proses \\
penyelesaian sengketa hak pakai atas tanah hak milik. Metode
\end{tabular}


DOI:

10.47268/ballrev.v2i1.560 yang digunakan dalam penelitian ini ialah metode yuridis normatif dengan menggunakan pendekatan Undang-undang dan pendekatan konseptual, dan pendekatan kasus kemudian dikaji dan dijadikan sebagai bahan analisa secara deskriptif guna memperoleh hasil jawaban terhadap permasalahn yang terjadi. Hasil penelitian yang diperoleh bahwa pengaturan hak pakai atas tanah hak milik menjadi hal yang sangat penting diperhatikan karena, ketika hak pakai berdiri bangunanbangunan atau benda-benda yang kemudian menjadi aset pihak penerima hak pakai. Maka ketika hak pakai tersebut habis waktu atau dibatalkan akan berdampak hukum atas benda-benda yang ada di atasnya, dengan demikian diharapkan bahwa harus adanya peraturan yang mengatur tentang benda-benda atau bangunan-bangunan yang dikutsertakan dalam pelepasan hak pakai walaupun ada perjanjajian yang dilakukan oleh para pihak.

\section{Pendahuluan}

Republik Indonesia merupakan Negara Agraria (pertanian) yang mempunyai sumber alam yang melimpah ruah, akan tetapi kekayaan yang demikian besar sebagai karunia Tuhan Yang Maha Kuasa itu belum dapat dinikmati oleh rakyat. Tampaknya kekayaan alam itu dimiliki oleh sebagian kecil orang Indonesia. Sistem yang merugikan rakyat seperti itu sudah berlangsung sejak zaman penjajahan Belanda.

Menurut konsepsi hukum tanah nasional, seluruh bumi, air dan ruang angkasa termasuk kekayaan alam yang terkandung didalamnya merupakan karunia Tuhan Yang Maha Esa dan merupakan kekayaan nasional, sehingga semua tanah yang ada di dalam wilayah negara kita adalah tanah bersama seluruh rakyat Indonesia, yang bersatu menjadi Bangsa Indonesia (Pasal 1 ayat (1) ) Undang-Undang Nomor 5 Tahun 1960 Tentang Peraturan Dasar Pokok-Pokok Agraria (selanjutnya disebut UUPA) (Lawalata et al., 2021: 18).

UUPA tidak mengatur ihwal tanahnya, melainkan soal hak atas permukaan bumi saja. Jadi, tidak termasuk seluruh bumi, air dan kekayaan alam yang terkandung di dalamnya. Tanah yang dimaksud dalam UUPA tidak sama dengan tanah yang dimaksud dalam KUH Perdata sebagai benda tak bergerak, tetapi tanah dalam UUPA memiliki asas yang sangat spesifik dan merupakan kultur budaya bangsa Indonesia. Dalam UUPA terdapat unsur komunalistik religious artinya ketentuan hukum Indonesia melihat bahwa tanah itu adalah milik bersama yang diberikan oleh sang pencipta guna kesejahteraan masyarakat, berarti Indonesia mengatur prinsip Negara kesejahteraan. Sebagai Negara kesejahteraan, Negara Indonesia mengikuti asas bahwa peraturan yang lebih rendah tidak boleh bertentangan atau menyimpang dari peraturan yang lebih tinggi tingkatannya. Karena itu Negara memiliki tugas dan tanggung jawab khusus yaitu memberikan keadilan dalam penguasaan dan pemilikan hak atas tanah sesuai dengan falsafah Pancasila (Rooy et al., 2021: 44).

Berdasarkan Undang-Undang Nomor 5 Tahun 1960 tentang Peraturan Dasar Pokok Agraria, Hak Pakai diatur dalam Pasal 41 sampai dengan Pasal 43 yang diatur lebih lanjut dalam Peraturan Pemerintah Nomor 40 tahun 1996 tentang Hak Guna Usaha, Hak Guna Bangunan dan Hak Pakai Atas Tanah Pasal 41 sampai dengan Pasal 58. Dalam Pasal 41 ayat (1) UUPA didefinisikan bahwa Hak Pakai adalah: "hak untuk menggunakan dan/atau memungut hasil dari tanah yang dikuasai langsung oleh negara atau tanah Hak Milik orang 
lain, yang memberi wewenang dan kewajiban yang ditentukan dalam keputusan pemberiannya oleh pejabat yang berwenang memberikannya atau dalam perjanjian dengan pemilik tanahnya, yang bukan perjanjian sewa menyewa atau perjanjian pengolahan tanah, segala sesuatu asal tidak bertentangan dengan jiwa dan ketentuan-ketentuan undangundang ini".

Perkataan "menggunakan" dalam pengertian Hak Pakai sebagaimana tersebut diatas menunjuk pada pengertian bahwa Hak Pakai digunakan untuk kepentingan mendirikan bangunan. Sedangkan perkataan "memungut hasil" dari pengertian diatas adalah menunjuk pada pengertian bahwa Hak Pakai digunakan untuk kepentingan selain mendirikan bangunan, misalnya pertanian, perikanan, peternakan, perkebunan (Santoso, 2017: 119).

Berdasarkan uraian Pasal 41 UUPA Hak Pakai adalah hak untuk menggunakan dan memungut hasil dari tanah yang dikuasai langsung oleh Negara atau tanah milik orang lain. Sebagaimana diatur dalam Pasal 42 Hukum Tanah, Hak pakai atas tanah dapat diberikan kepada:

1) Warga negara Indonesia;

2) Orang asing yang berkedudukan di Indonesia;

3) Badan hukum yang didirikan dan berkedudukan di Indonesia;

4) Badan hukum asing yang mempunyai kantor perwakilan di Indonesia.

Lebih lanjut, sebagaimana diatur dalam Peraturan Pemerintah Nomor 40 Tahun 1996 tentang Hak Guna Usaha, Hak Guna Bangunan, dan Hak Pakai Atas Tanah , Hak Pakai dapat diberikan di atas tanah dengan status:

1) Tanah Negara;

2) Tanah hak pengelolaan;

3) Tanah hak milik.

Kepemilikan properti oleh Warga Negara Asing (Selanjutnya disebut WNA) sebagaimana diatur secara khusus dalam Peraturan Pemerintah Nomor 41 Tahun 1996 mengenai Pemilikan Rumah Tempat Tinggal atau Hunian oleh Orang Asing yang Berkedudukan di Indonesia. Pasal 2 Peraturan Pemerintah No. 41 Tahun 1996 yang menyebutkan jenis rumah yang diperbolehkan untuk dimiliki oleh orang asing yaitu:

1) Rumah yang dibangun di atas tanah negara;

2) Rumah yang dibangun berdasarkan perjanjian dengan pemegang hak milik atas tanah. Perjanjian tersebut harus dibuat di hadapan Pejabat Pembuat Akta Tanah;

3) Satuan rumah susun yang dibangun di atas Hak Pakai atas tanah Negara.

Terjadinya hak pakai atas tanah negara adalah melalui keputusan pemberian hak oleh menteri atau pejabat yang ditunjuk. Terjadinya hak pakai atas hak pengelolaan adalah melalui keputusan pemberian hak oleh menteri atau pejabat yang ditunjuk berdasarkan usul pemegang hak pengelolaan. Sedangkan untuk hak pakai atas tanah hak milik terjadi melalui pemberian tanah oleh pemegang hak milik dengan akta yang dibuat oleh Pejabat Pembuat Akta Tanah. Setiap pemberian hak pakai tersebut wajib didaftarkan dalam buku tanah pada Kantor Pertanahan.

Proses terjadinya hak pakai atas tanah hak milik tersebut berdasarkan aturan perundang-undangan adalah untuk mencegah penyalahgunaan proses jalannya administrasi. Namun dalam era kehidupan yang semakin modern ini, terdapat banyak sengketa yang terjadi berkaitan dengan penguasaan dan penggunaan tanah baik untuk kepentingan umum maupun kepentingan individu, yang melibatkan banyak pihak baik 
pemerintah dengan masyarakat, masyarakat dengan masyarakat, maupun pihak swasta dengan masyarakat, antara perorangan dengan perorangan bahkan perorangan dengan WNA.

Selanjtnya penggunaan hak pakai atas tanah hak milik yang dimaksud tersebut adalah penggunaan hak pakai oleh WNA yang menggunakan Tanah/Bangunan untuk tempat tinggal dan beraktifitas di Indonesia. Berdasarkan Pasal 45 Peraturan Pemerintah Nomor 40 Tahun 1996, Hak Pakai atas Tanah Negara diberikan untuk jangka waktu 25 (dua puluh lima) tahun, dapat diperpanjang selama 20 (dua puluh) tahun, dan diperbaharui untuk jangka waktu 25 (dua puluh lima) tahun. Hak Pakai di atas tanah Hak Pengelolaan dapat diperpanjang dan diperbaharui atas usul pemegang Hak Pengelolaan, sedangkan Hak Pakai yang terjadi di atas tanah Hak Milik tidak dapat diperpanjang, tetapi dapat diperbaharui atas kesepakatan antara pemegang Hak Milik dan pemegang Hak Pakai.

Apabila WNA sebagai pemegang Hak Pakai tidak lagi memenuhi syarat sebagai subyek hak yang berkedudukan di Indonesia, maka akibat hukumnya adalah WNA tersebut wajib melepaskan atau mengalihkan haknya kepada pihak lain yang memenuhi syarat dalam jangka waktu 1 (satu) tahun. Bila dalam jangka waktu satu tahun, haknya tidak dilepaskan atau dialihkan, hak tersebut hapus karena hukum dengan ketentuan hak-hak pihak lain yang terkait di atas tanah tersebut tetap diperhatikan.

Hak pakai sama sekali bukan lembaga hak atas tanah yang baru, namun kurang dikenal jika dibandingkan dengan hak milik, hak guna usaha, atau hak guna bangunan, untuk itu diperlukan pemahaman yang benar mengenai hak pakai agar dapat menggunakannya secara bertanggungjawab. Sengketa yang terjadi disebabkan oleh kurangnya pemahaman tentang penggunaan, pengelolaan dan proses-proses dalam pengurusan hak pakai atas tanah yang berbasis hak milik.

\section{Metode Penelitian}

Jenis penelitian yang digunakan dalam penelitian adalah penelitian hukum normatif. Penelitian hukum normatif adalah: suatu proses untuk menemukan suatu aturan hukum, prinsip-prinsip hukum, maupun doktrin-doktrin hukum guna menjawab isu hukum yang dihadapi (Marzuki, 2016: 35). Pendekatan yang dipakai dalam penelitian ini adalah pendekatan perundang-undangan (Statute Approach). Pendekatan Undang-undang ini dilakukan dengan menelaah semua undang-undang dan regulasi yang bersangkut paut dengan isu hukum yang sedang ditangani (Marzuki, 2016: 93). Selanjutnya adalah Pendekatan Kasus (Case Approach) dalam pendekatan kasus ini dilakukan dengan cara menelaah kasus-kasus terkait dengan isu yang sedang dihadapi, dan telah menjadi putusan yang mempunyai kekuatan hukum tetap. Pendekatan yang berikut adalah Pendekatan Konseptual (Conceptual Approach), merupakan pendekatan yang beranjak dari pandanganpandangan, doktrin-doktri yang berkembang di dalam ilmu hukum. Pendekatan konseptual digunakan untuk mengkaji dan menganalisis kerangka konseptual maupun kerangka teoritis sesuai dengan tujuan penelitian (Marzuki, 2016: 94). Analisis sumber hukum yang digunakan dalam penelitian ini adalah analisa kualitatif yaitu analisa dengan menggunakan bahan hukum primer dan sekunder yang diuraikan secara deskriptif. Teknik pengumpulan bahan hukum yang digunakan adalah dengan melakukan studi dokumen atau menggunakan literatur untuk pengumpulan bahan-bahan hukum yang diperlukan yang berasal dari beberapa bahan hukum primer, bahan hukum sekunder dan bahan hukum tertier. Bahan-bahan Hukum yang telah terkumpul baik dari studi kepustakaan, dokumendokumen tersebut diolah dan dianalisis secara deskriptif kemudian dianalisis setelah itu 
dihubungkan dengan teori-teori, asas-asas dan norma-norma hukum yang berhubungan dengan permasalahan tersebut.

\section{Hasil dan Pembahasan}

\subsection{Pengaturan Hak Pakai Atas Tanah Hak Milik}

Tanah merupakan salah satu komponen ekosistem yang sangat strategis bagi kelangsungan hidup umat manusia, dan juga sebagai faktor utama dalam setiap kegiatan pembangunan. Hubungan manusia dengan tanah yang kuat menuntut jaminan perlindungan hukum agar manusia dapat melaksanakan hak-haknya secara aman (Hetharie, 2019: 27). Peran tanah yang begitu besar maka negara berkewajiban untuk mengatur penggunaan dan peruntukan tanah, sebagai mana yang diatur dalam Pasal 33 ayat (3) Undang-Undang Dasar Negara Republik Indonesia Tahun 1945 yang menyatakan: “Bumi dan air dan kekayaan alam yang terkandung didalamnya dikuasi oleh Negara dan dipergunakan untuk sebesar-besar kemakmuran rakyat". Bumi, air dan kekayaan alam yang terkandung didalamnya begitu pula ruang angkasa merupakan karunia Tuhan Yang Maha Esa kepada seluruh rakyat Indonesia dan oleh karena itu sudah semestinya pemanfaatannya haruslah tetap memerlukan tanah.

Selain diatur dalam UUD NRI Tahun 1945, Hak Pakai juga diatur dalam Pasal 41 sampai dengan Pasal 43 yang diatur lebih lanjut dalam Peraturan Pemerintah Nomor 40 Tahun 1996 tentang Hak Guna Usaha, Hak Guna Bangunan dan Hak Pakai Atas Tanah Pasal 41 sampai dengan Pasal 58. Dalam Pasal 41 ayat (1) UUPA, didefinisikan bahwa Hak Pakai adalah hak untuk menggunakan dan/atau memungut hasil dari tanah yang dikuasai langsung oleh Negara atau tanah Hak Milik orang lain, yang memberi wewenang dan kewajiban yang ditentukan dalam keputusan pemberiannya oleh pejabat yang berwenang memberikannya atau dalam perjanjian dengan pemilik tanahnya, yang bukan perjanjian sewa menyewa atau perjanjian pengolahan tanah, segala sesuatu asal tidak bertentangan dengan jiwa dan ketentuan-ketentuan undang-undang ini.

Hak Pakai dapat diberikan kepada:

1) Warga Negara Indonesia;

2) Orang asing yang berkedudukan di Indonesia;

3) Badan hukum yang didirikan menurut hukum Indonesia dan berkedudukan di Indonesia;

4) Departemen, Lembaga Pemerintah Non Departemen, dan Pemerintah Daerah;

5) Badan-badan keagamaan dan sosial;

6) Badan hukum asing yang mempunyai perwakilan di Indonesia;

7) Perwakilan negara asing dan perwakilan Badan Internasional.

Pelepasan hak atas tanah dapat diserahkan secara sukarela atau ada ganti rugi kepada pemilik tanah. Penyerahan secara sukarela atau dengan ganti rugi inilah yang disebut melepaskan hak, dalam prakteknya istilah sukarela itu tidak murni lagi, sebab ada unsur ganti rugi, dalam bahasa sehari-hari penyerahan sukarela seperti itu adalah akibat tindakan penggusuran oleh suatu pihak yang menang dalam sengketa tanah di pengadilan (Hallauw et al., 2020: 114). Perlindungan hukum dan dengan memberikan ganti kerugian yang adil dan layak kepada pihak yang berhak, akan tetapi kenyataannya seringkali pemegang hak atas yang memberikan haknya mengalami penurunan kualitas dibandingkan keadaannya semula sebelum pelepasan hak atas tanah (Kotalewala et al., 2020: 415-516). 
Pada dasarnya Hak Pakai dapat dialihkan, dalam hal terdapat tanah yang merupakan tanah yang dikuasai oleh negara, maka Hak Pakai hanya dapat dialihkan kepada pihak lain dengan izin pejabat yang berwenang. Namun, apabila terdapat tanah yang merupakan tanah hak milik, maka pengalihan Hak Pakai kepada pihak lain hanya dimungkinkan apabila dinyatakan secara tegas dalam perjanjian. Jadi, apabila dalam suatu kejadian pemegang Hak Pakai kehilangan persyaratannya atas hak tersebut, maka pihak tersebut akan kehilangan haknya dan wajib mengalihkannya kepada pihak lain atau Hak Pakai tersebut dihapuskan. Menjadi hal yang sangat penting untuk dibahas adalah ketika atas hak pakai berdiri bangunan-bangunan atau benda-benda yang kemudian menjadi aset pihak penerima hak pakai. Ketika hak pakai tersebut habis waktu atau dibatalkan akan berdampak hukum atas benda-benda yang ada di atasnya. Maka dari itu membicarakan hak pakai tidak akan terlepas dari perjanjian pendahulu yang mengiringi diterbitkannya hak pakai tersebut. Sehubungan dengan pelaksanaan hak pakai atas tanah ditetapkan/dilaksanakan dalam bentuk perjanjian. Maka suatu perjanjian pemberian hak pakai tanah ini harus mengikuti kaidah-kaidah hukum perjanjian. Untuk sahnya suatu perjanjian diperlukan 4 (empat) syarat yang harus dipenuhi, yang diatur dalam Pasal 1320 KUH Perdata, yaitu:

1) Sepakat mereka yang mengikatkan dirinya;

2) Cakap untuk membuat suatu perikatan;

3) Suatu hal tertentu;

4) Suatu sebab yang halal.

Syarat sahnya suatu perjanjian yang kesatu (sepakat mereka yang mengikatkan dirinya) dan syarat kedua (cakap untuk membuat suatu perjanjian) disebut syarat subjektif, karena menyangkut subjek hukum yaitu orang-orang atau pihak-pihak yang membuat perjanjian. Sedangkan syarat ketiga (objek suatu hal tertentu) dan syarat keempat (sebab atau causa yang halal) disebut sebagai objektif, karena menyangkut objek hukum yang diperjanjikan oleh orang-orang atau pihak-pihak yang membuat perjanjian tersebut (Muhammad, 2012: 110).

Penting untuk diperhatikan atas perjanjian yang dibuat sebelum adanya hak pakai karena benda-benda yang ada di atasnya akan dipisahkan dengan tanah yang menjadi objek hukum hak pakai. Tanah yang melekat hak pakai dapat diberikan untuk kepentingan umum dimana selanjutnya kepemilikan atas benda-benda dan aktifitas di atasnya menjadi tanggungjawab pemerintah dengan menjadi aset negara. Pada prinsipnya hak pakai merupakan aset negara jadi ketika hak pakai tersebut telah dibatalkan dan terdapat bangunan di atasnya maka sesungguhnya pemilik hak pakai tidak memiliki perhitungan hukum untuk penguasaan apalagi kepemilikan aset di atas hak pakai. Hal ini berhubungan dengan hak guna bangunan. Ketika tanah hak pakai adalah aset negara maka ada baiknya subyek hukum mengurus hak guna bangunan, karena hal ini akan menjadi perhitungan atau pertimbangan hukum saat hak pakai telah habis masa waktu atau batal.

Selanjutnya Hak Pakai atas tanah Hak Milik diberikan untuk jangka waktu paling lama dua puluh lima tahun dan tidak dapat diperpanjang. Atas kesepakatan antar pemegang Hak Pakai dengan pemegang Hak Milik, Hak Pakai atas tanah Hak Milik dapat diperbaharui dengan pemberian Hak Pakai baru dengan akta yang dibuat oleh Pejabat Pembuat Akta Tanah dan hak tersebut wajib didaftarkan ke Kantor Pertanahan Kabupaten/Kota setempat untuk dicatat dalam Buku Tanah. Bentuk akata PPAT ini dimuat dalam Lampiran Peremen Agraria/Kepala BPN No.3 Tahun 1997.

Objek Hak Pakai, Tanah yang dapat diberikan Hak Pakai berdasarkan Pasal 41 PP No. 40/1996 adalah tanah negara, tanah Hak Pengelolaan dan tanah Hak Milik. Pemberian Hak 
Pakai diberikan melalui keputusan Menteri atau pejabat berwenang. Hak Pakai suatu tanah Hak Pengelolaan diberikan melalui keputusan menteri atau pejabat berwenang dengan usulan dari pemegang hak pengelolaan. Hal ini berlaku untuk tanah negara. Sedangkan untuk tanah Hak Milik, maka Hak Pakai diberikan melalui perjanjian kedua pihak. Jangka Waktu Hak Pakai dapat diberikan maksimal 25 (dua puluh lima) tahun dan dapat diperpanjang selama maksimal 20 (dua puluh) tahun. Pembaharuan juga dapat diberikan setelah Hak Pakai dan perpanjangannya berakhir. Hak Pakai dari tanah negara dapat diperpanjang dan diperbaharui bila tanahnya masih dalam kondisi baik, pemegang hak memenuhi persyaratan menjadi subjek Hak Pakai. Hak Pakai sebuah tanah pengelolaaan dapat diperpanjang dan diperbaharui dengan adanya usul dari pemegang hak pengelolaan. Hak Pakai dari tanah hak milik hanya dapat diberikan untuk 25 (dua puluh lima) tahun dan tidak dapat diperpanjang. Pengalihan dan Penghapusan Hak Pakai dari sebuah tanah negara hanya dapat dilakukan setelah keputusan menteri atau pejabat berwenang. Untuk sebuah tanah Hak Milik, maka Hak Pakai hanya dapat dialihkan bila hal tersebut diperjanjikan. Pengalihan hanya dapat terjadi karena jual beli, tukar menukar, penyertaan dalam modal, hibah, pewarisan.

\section{Hak Pakai dapat hilang karena:}

1) Berakhir jangka waktu;

2) Dibatalkan pejabat yang berwenang, pemegang hak pengelolaan atau pemegang hak milik sebelum jangka waktu berakhir karena:

3) Tidak dipenuhi kewajiban-kewajiban pemegang Hak Pakai.

4) Tidak dipenuhi syarat atau kewajiban yang tertulis dalam perjanjian antara para pihak mengenai pemberian hak pakai atau penggunaan hak pengelolaan.

5) Putusan pengadilan yang telah mempunyai kekuatan hukum yang tetap.

6) Diberikan secara sukarela;

7) Ditelantarkan;

8) Tanahnya musnah;

9) Pemegang Hak Pakai tidak melepaskan atau mengalihan hak nya kepada pihak ketiga, dalam waktu satu tahun sejak pemegang Hak Pakai tidak lagi memenuhi persyaratan sebagai pemegang Hak Pakai sebagaimana diatur dalam Pasal 39 Peraturan Pemerintah Nomor 40 Tahun 1996.

Sementara berdasarkan Pasal 42 UUPA, Hak Pakai hanya bisa diberikan kepada Warga Negara Indonesia (WNI), orang asing yang berkedudukan di Indonesia, badan hukum yang didirikan menurut hukum Indonesia dan berkedudukan di Indonesia, serta badan hukum asing yang mempunyai perwakilan di Indonesia.

Selanjutnya Hak Pakai atas Tanah Milik perorangan tidak bisa diperpanjang, namun tetap dapat diperbaharui berdasarkan kesepakatan dengan pemegang Hak Milik atas tanah tersebut. (Pasal 49 ayat (2) PP No. 40/1996). Prosedur peningkatan status Hak Milik dapat diberikan atas tanah Hak Pakai yang dijadikan rumah tinggal kepunyaan perseorangan WNI yang luasnya $600 \mathrm{~m} 2$ atau kurang atas permohonan dari yang bersangkutan (pemegang hak pakai tersebut). Hal ini seperti tertuang pada Keputusan Menteri Agraria/Kepala Badan Pertanahan Nasional Nomor 6 Tahun 1998 tentang Pemberian Hak Milik atas Tanah untuk Rumah Tinggal (“Kepmen No. 6/1998”). Sesuai Pasal 1 ayat (2) Kepmen No. 6/1998, untuk pemberian Hak Milik tersebut, si penerima hak harus membayar uang pemasukan kepada Negara sesuai ketentuan yang berlaku. 
Adapun persyaratan lain yang harus dipenuhi untuk meningkatkan status Hak Pakai menjadi Hak Milik adalah dengan mengajukan permohonan kepada Kepala Kantor Pertanahan Kabupaten/Kotamadya setempat, disertai dengan lampiran sebagai berikut:

1) Sertifikat tanah yang bersangkutan

2) Bukti penggunaan tanah untuk rumah tinggal berupa;

a) Fotokopi Izin Mendirikan Bangunan yang mencantumkan bahwa bangunan tersebut digunakan untuk rumah tinggal, atau

b) Surat keterangan dari Kepala Desa/Kelurahan setempat bahwa bangunan tersebut digunakan untuk rumah tinggal, apabila izin Mendirikan Bangunan tersebut belum dikeluarkan oleh instansi yang berwenang;

3) Fotokopi SPPT PBB yang terakhir (khusus untuk tanah yang luasnya $200 \mathrm{~m} 2$ atau lebih);

4) Bukti identitas pemohon;

5) Pernyataan dari pemohon bahwa dengan perolehan Hak Milik yang dimohon pendaftarannya itu, yang bersangkutan akan mempunyai Hak Milik atas tanah untuk rumah tinggal tidak lebih dari 5 (lima) bidang tanah seluruhnya, meliputi luas tidak lebih dari 5000 (lima ribu) m2.

Selanjutnya Kewajiban dan hak pemegang Hak Pakai diatur dalam Pasal 50 sampai dengan Pasal 52 Peraturan Pemerintah Nomor 40 Tahun 1996. Kewajiban pemegang Hak Pakai, yaitu :

1) Membayar uang pemasukan yang jumlah dan cara pembayarannya ditetapkan dalam keputusan pemberian haknya;

2) Menggunakan tanah sesuai dengan peruntukannya dan persyaratan sebagaimana yang ditetapkan dalam keputusan pemberiannya atau perjanjian penggunaan tanah Hak Pengelolaan atau perjanjian pemberian Hak Pakai atas Tanah Hak Milik;

3) Memelihara dengan baik tanah dan bangunan yang ada di atasnya serta menjaga kelestarian lingkungan hidup;

4) Menyerahkan kembali tanah yang diberikan dengan Hak Pakai kepada Negara, pemegang Hak Pengelolaan atau pemegang Hak Milik sesudah Hak Pakai hapus;

5) Menyerahkan sertipikat Hak Pakai yang telah hapus kepada Kepala Kantor Pertanahan;

6) Jika tanah Hak Pakai karena keadaan geografis atau lingkungan atau sebab sebab lain letaknya sedemikian rupa sehingga mengurung atau menutup pekarangan atau sebidang tanah lain dari lalu lintas umum atau jalan air, pemegang Hak Pakai wajib memberikan jalan keluar atau jalan air atau kemudahan lain bagi pekarangan atau bidang tanah yang terkurung.

Selanjutnya hak pakai atas tanah hak milik dapat dilaksanakan berdasarkan perjanjian yang dibuat di hadapan pejabat yang berwenang. Adapun dalam hubungannya dengan perjanjian sewa-menyewa, Pasal 44 UUPA menentukan bahwa:

(1) Seseorang atau suatu badan hukum mempunyai hak sewa atas tanah apabila ia berhak mempergunakan tanah milik orang lain untuk keperluan bangunan, dengan membayar kepada pemiliknya sejumlah uang sebagai sewa.

(2) Pembayaran uang sewa dapat dilakukan, 1 (satu) kali atau pada tiap-tiap waktu tertentu; dan sebelum atau sesudah tanahnya dipergunakan.

(3) Perjanjian sewa tanah yang dimaksudkan dalam pasal ini tidak boleh disertai syarat-syarat yang mengandung unsur pemerasan. 
Selanjutnya Suatu perjanjian adalah suatu peristiwa di mana seorang berjanji kepada seorang lain atau di mana dua orang itu saling berjanji untuk melaksanakan sesuatu hal. Dari peristiwa ini, timbulah suatu hubungan antara dua orang tersebut yang dinamakan perikatan. Perjanjian itu menerbitkan suatu perikatan antara dua orang yang membuatnya. Dalam bentuknya, perjanjian itu berupa suatu rangkaian perkataan yang mengandung janjijanji atau kesanggupan yang diucapkan atau ditulis. Untuk syarat sahnya perjanjian diperlukan empat syarat (Subekti, 2008: 17), yaitu:

1) Sepakat mereka yang mengikatkan dirinya;

Dengan sepakat dimaksudkan bahwa kedua subyek yang mengadakan perjanjian itu harus bersepakat, setuju atau seia-sekata mengenai hal-hal yang pokok dari perjanjian yang diadakan itu.

2) Cakap untuk membuat suatu perjanjian;

Orang yang membuat suatu perjanjian harus cakap menurut hukum. Pada asasnya, setiap orang yang sudah dewasa dan sehat pikirannya adalah cakap menurut hukum.

3) Mengenai suatu hal tertentu;

Mengenai suatu hal tertentu artinya apa yang diperjanjikan hak-hak dan kewajiban kedua belah pihak jika timbul suatu perselisihan dan suatu hal yang diperjanjikan harus jelas isinya.

4) Suatu sebab yang halal.

Artinya adalah perjanjian tersebut harus halal dalam arti bahwa isi perjanjian tidak boleh bertentangan dengan peraturan perundangan yang berlaku dan kesusilaan.

Pasal 2 angka 1 huruf b Peraturan Pemerintah Nomor 41 Tahun 1996 tentang Pemilikan Rumah Tempat Tinggal atau Hunian oleh Orang Asing yang Berkedudukan di Indonesia menyebutkan bahwa WNA dapat memiliki rumah yang berdiri sendiri di atas bidang tanah Hak Pakai atas Tanah Negara atau di atas bidang tanah yang dikuasai berdasarkan perjanjian dengan pemegang hak atas tanah.

Sebelum diterbitkannya Peraturan Pemerintah Nomor 41 Tahun 1996 tentang Pemilikan Rumah Tempat Tinggal atau Hunian oleh Orang Asing yang Berkedudukan di Indonesia, alternatif bagi WNA yang memerlukan rumah/hunian adalah dengan mengadakan perjanjian sewa menyewa rumah/bangunan yang sudah ada di atas sebidang tanah untuk dihuni tanpa penguasaan hak atas tanahnya. Pengertian sewa menyewa dalam KUHPerdata Pasal 1548 berbunyi : "Sewa menyewa ialah suatu persetujuan, dengan mana pihak yang satu mengikatkan dirinya untuk memberikan kepada pihak lainnya untuk kenikmatan dari suatu barang, selama suatu waktu tertentu dan dengan pembayaran suatu harga, yang oleh pihak tersebut belakangan itu disanggupi pembayarannya."

Perjanjian sewa-menyewa, penguasaan tanah oleh penyewa bangunan hanyalah dalam hubungan dengan perjanjian sewa menyewa bangunan tersebut (Hamzah et al., 2006: 55), dalam Perjanjian Pendahuluan Pemberian Hak Pakai Atas Tanah Hak Milik terdapat hal-hal yang diperjanjikan antara kedua belah pihak, yaitu antara Pemberi Hak Pakai sebagai Pihak Pertama dan Penerima Hak Pakai sebagai Pihak Kedua. Hal-hal yang diperjanjikan dalam Perjanjian Pendahuluan Pemberian Hak Pakai Atas Tanah Hak Milik diantaranya adalah sebagai berikut sebagaimana terlampir dalam Perjanjian Pendahuluan Pemberian Hak Pakai Atas Tanah Hak Milik (Ayu, 2010: 84):

1) Janji Untuk Memberikan Hak Pakai Atas Tanah dan Untuk Menerima Hak Pakai Atas Tanah;

2) Kewajiban Pemberi Hak Pakai selaku Pihak Pertama; 
3) Kewajiban Penerima Hak Pakai selaku Pihak Kedua;

4) Uang Ganti Kerugian;

5) Pernyataan dan Jaminan Pemberi Hak Pakai selaku Pihak Pertama;

6) Pernyataan dan Jaminan Penerima Hak Pakai selaku Pihak Kedua;

7) Pelaksanaan Pemberian Hak Pakai Atas Tanah;

8) Pajak dan Biaya;

9) Aneka Ketentuan.

Pada intinya, Perjanjian Pendahuluan Pemberian Hak Pakai Atas Tanah Hak Milik dibuat dalam bentuk akta otentik dan dibuat dihadapan Notaris oleh kedua belah pihak yaitu antara Pemberi Hak Pakai sebagai Pihak Pertama dan Penerima Hak Pakai sebagai Pihak Kedua. Perjanjian Pendahuluan Pemberian Hak Pakai Atas Tanah Hak Milik tersebut dibuat sebelum sertipikat penggabungan selesai dan sebelum dilaksanakannya pembuatan dan penandatanganan Akta Pemberian Hak Pakai Atas Tanah Hak Milik. Tujuan dari dibuatnya Perjanjian Pendahuluan Pemberian Hak Pakai Atas Tanah Hak Milik adalah untuk mengikat para pihak yaitu dengan memberikan hak pakai atas tanah dan menerima hak pakai atas tanah. Dalam Perjanjian Pendahuluan Pemberian Hak Pakai Atas Tanah Hak Milik tersebut diantaranya memuat kesepakatan antara Pemberi Hak Pakai sebagai Pihak Pertama untuk memberikan Hak Pakai atas tanah kepada Penerima Hak Pakai sebagai Pihak Kedua untuk jangka waktu 25 (dua puluh lima) tahun.

\subsection{Proses Penyelesaian Sengketa Hak Pakai Atas Tanah Hak Milik}

Pemerintah tidak cukup hanya dengan melakukan redistribusi dan legalisasi aset pertanahan. Namun, pemerintah juga perlu segera melakukan penyelesaian konflik dan sengketa pertanahan. Di sisi lain, untuk dapat menyelesaikan sengketa pertanahan, diperlukan data administrasi pertanahan lengkap, pembenahan kelembagaan, serta regulasi yang memadai (Saija et al., 2020: 106). Penyelesaian sengketa yang telah ditempuh selama ini adalah melalui pengadilan (litigasi), seiring dengan perjalanan waktu, penyelesaian sengketa melalui cara musyawarah semakin bayak di lakukan. Sengketa pertanahan yang lebih banyak berkaitan dengan masalah kepentingan atau interes para pihak, relatif lebih mudah untuk diselesaikan melalui cara musyawarah sepanjang kedua belah pihak saling terbuka dan menginginkan jalan keluar yang terbaik bagi semua pihak (Laturette, 2021: 103).

Sengketa pertanahan dirumuskan dalam Pasal 1 Peraturan Menteri Negara Agraria/Kepala Badan Pertanahan Nasional Nomor 1 tahun 1999 tentang Tata Cara Penanganan Sengketa Pertanahan, (selanjutnya disebut PMNA/KBPN 1/1999), yaitu : “ perbedaan pendapat antara pihak yang berkepentingan mengenai keabsahan suatu hak, pemberian hak atas tanah, pendaftaran hak atas tanah, termasuk peralihan dan penerbitan tanda bukti haknya serta pihak yang berkepentingan yang merasa mempunyai hubungan hukum dan pihak lain yang berkepentingan terpengaruh oleh status hukum tanah tersebut."

Menurut Sarjita, sengketa pertanahan adalah: "perselisihan yang terjadi antara dua pihak atau lebih yang merasa atau dirugikan pihak-pihak tersebut untuk penggunaan dan penguasaan hak atas tanahnya, yang diselesaikan melalui musyawarah atau melalui pengadilan (Sarjita, 2008: 8)."

Sifat permasalahan dari suatu sengketa ada beberapa macam (Murad, 1991: 23):

1) Masalah yang menyangkut prioritas untuk dapat ditetapkan sebagai pemegang hak yang sah atas tanah yang berstatus hak atas tanah yang belum ada haknya.

2) Bantahan terhadap sesuatu alas hak/bukti perolehan yang digunakan sebagai dasar pemberian hak. 
3) Kekeliruan/kesalahan pemberian hak yang disebabkan penerapan peraturan yang kurang/tidak benar.

4) Sengketa/masalah lain yang mengandung aspek-aspek sosial praktis (bersifat strategis). Jadi dilihat dari substansinya, maka sengketa pertanahan meliputi pokok persoalan yang berkaitan dengan :

a) Peruntukan dan/atau penggunaan serta penguasaan hak atas tanah;

b) Keabsahan suatu hak atas tanah;

c) Prosedur pemberian hak atas tanah; dan

d) Pendaftaran hak atas tanah termasuk peralihan dan penerbitan tanda bukti haknya.

Berdasarkan Undang-Undang Nomor 5 Tahun 1960 tentang Peraturan Dasar Pokok Agraria, Hak Pakai diatur dalam Pasal 41 sampai dengan Pasal 43 yang diatur lebih lanjut dalam Peraturan Pemerintah Nomor 40 tahun 1996 tentang Hak Guna Usaha, Hak Guna Bangunan dan Hak Pakai Atas Tanah Pasal 41 sampai dengan Pasal 58, dalam Pasal 41 ayat (1) Undang-Undang Pokok Agraria, didefinisikan bahwa Hak Pakai adalah hak untuk menggunakan dan/atau memungut hasil dari tanah yang dikuasai langsung oleh negara atau tanah Hak Milik orang lain, yang memberi wewenang dan kewajiban yang ditentukan dalam keputusan pemberiannya oleh pejabat yang berwenang memberikannya atau dalam perjanjian dengan pemilik tanahnya, yang bukan perjanjian sewa menyewa atau perjanjian pengolahan tanah, segala sesuatu asal tidak bertentangan dengan jiwa dan ketentuanketentuan undang-undang ini.

Pasal 50 Peraturan Pemerintah Nomor 40 Tahun 1996 tentang Hak Guna Usaha, Hak Guna Bangunan dan Hak Pakai Atas Tanah mengenai Kewajiban dan Hak Pemegang Hak Pakai yang menyebutkan:

a) Membayar uang pemasukan yang jumlah dan cara pembayarannya ditetapkan dalam keputusan pemberian haknya, perjanjian penggunaan tanah Hak Pengelolaan atau dalam perjanjian pemberian Hak Pakai atas tanah Hak Milik.

b) Menggunakan tanah sesuai dengan peruntukannya dan persyaratan sebagaimana ditetapkan dalam keputusan pemberiannya, atau perjanjian pemberian Hak Pakai atas tanah Hak Milik.

c) Memelihara dengan baik tanah dan bangunan yang ada di atasnya serta menjaga kelestarian lingkungan hidup.

d) Menyerahkan kembali tanah yang diberikan dengan Hak Pakai kepada Negara, pemegang Hak Pengelolaan atau pemegang Hak Milik sesudah Hak Pakai tersebut hapus.

e) Menyerahkan sertipikat Hak Pakai yang telah hapus kepada Kepala Kantor Pertanahan.

Selanjutnya apabila hak pakai tersebut menimbulkan akibat hukum maka Hak Pakai Atas Tanah tersebut dibatalkan. Pasal 55 ayat (1) Peraturan Pemerintah Nomor 40 Tahun 1996 tentang Hak Guna Usaha, Hak Guna Bangunan dan Hak Pakai Atas Tanah menerangkan bahwa hapusnya Hak Pakai dikarenakan :

a) Berakhirnya jangka waktu sebagaimana ditetapkan dalam keputusan pemberian atau perpanjangannya atau dalam perjanjian pemberiannya.

b) Dibatalkan oleh pejabat yang berwenang, pemegang Hak Pengelolaan atau pemegang Hak Milik sebelum jangka waktunya berakhir, karena :

1) Tidak dipenuhinya kewajiban-kewajiban pemegang hak dan/atau dilanggarnya ketentuan-ketentuan sebagaimana dimaksud dalam Pasal 50, 
Pasal 51 dan Pasal 52; atau

2) Tidak dipenuhinya syarat-syarat atau kewajiban-kewajiban yang tertuang dalam perjanjian pemberian Hak Pakai antara pemegang Hak Pakai dan pemegang Hak Milik atau perjanjian penggunaan Hak Pengelolaan; atau

3) Putusan pengadilan yang telah mempunyai kekuatan hukum yang tetap.

Pembatalan Hak Atas Tanah dapat ditemukan di Pasal 34 huruf b dan Pasal 40 huruf b UUPA yang berbunyi “ dihentikan sebelum jangka waktunya berakhir karena sesuatu syarat tidak dipenuhi', Pasal 1 angka 14 Peraturan Menteri Negara Agraria / Kepala Badan Pertanahan Nasional (PMNA/KBPN) Nomor 9 Tahun 1999 tentang Tata Cara Pemberian dan Pembatalan Hak Atas Tanah Negara dan Hak Pengelolaan : "pembatalan Hak Atas Tanah adalah pembatalan keputusan pemberian hak atas tanah atau sertipikat hak atas tanah karena keputusan tersebut mengandung cacat hukum administrasi dalam penerbitannya atau untuk melaksanakan putusan pengadilan yang sudah memperoleh kekuatan hukum tetap". Badan Pertanahan Nasional (BPN) mempunyai kewenangan dalam membatalkan hak atas tanah. Hal ini tertera didalam Peraturan Kepala Badan Pertanahan Nasional Republik Indonesia Nomor 11 tahun 2016 tentang Penyelesaian Kasus Pertanahan, peraturan ini, dalam melakukan pembatalan hak atas tanah, melakukan pembagian kewenangan, yakni kewenangan kementrian dan kewenangan bukan kementrian.

Pengelompokan kewenangan ini, Badan Pertanahan Nasional bisa melakukannya dengan dua cara, Cara yang pertama yaitu dengan menjalankan amar putusan pangadilan yang telah memperoleh kekuatan hukum tetap. Hal ini lebih rinci dijelaskan didalam Pasal 49 ayat (2) yang menyatakan bahwa amar putusan pengadilan yang telah memperoleh kekuatan hukum tetap, yang berkaitan dengan penerbitan, peralihan dan/atau pembatalan hak atas tanah, antara lain:

a) Perintah untuk membatalkan hak atas tanah.

b) Menyatakan batal/tidak sah/tidak mempunyai kekuatan hukum hak atas tanah;

c) Menyatakan tanda bukti hak tidak sah/ tidak berkekuatan hukum;

d) Perintah dilakukannya pencatatan atau pencoretan dalam buku tanah;

e) Perintah penerbitan hak atas tanah;

f) Perintah untuk membatalkan penetapan tanah terlantar; dan

g) Amar yang bermakna menimbulkan akibat hukum terbitnya, atau beralihnya atau batalnya hak.

Cara yang kedua adalah, Badan Pertanahan Nasional (BPN) melakukan pembatalan pemberian hak tanpa adannya putusan dari pengadilan. Klasifikasi permasalahan sengketa termuat secara rinci pada Pasal 11 ayat (3) Peraturan Kepala Badan Pertanahan Nasional Republik Indonesia Nomor 11 tahun 2016 tentang Penyelesaian Kasus Pertanahan.

Penyelesaian kasus pertanahan diluar pengadilan dapat berupa perbuatan hukum administrasi hal ini tersebut dalam Pasal 24, 25, 26. Sedangkan untuk mengenai pelaksanaan keputusan penyelesaian kasus pertanahan tersebut secara rinci pada Pasal 27, 28, 29, dimana keputusan penyelesaian sengketa atau konflik dilaksanakan oleh Kepala Kantor Pertanahan.

Terkait sengketa tanah, ada peraturan terbaru terkait kasus pertanahan yaitu Peraturan Menteri Agraria dan Tata Ruang/Kepala Badan Pertanahan Nasional Nomor 11 Tahun 2016 tentang Penyelesaian Kasus Pertanahan

Dalam Permen Agraria Nomor 11 Tahun 2016, yang disebut dengan kasus pertanahan adalah Sengketa, Konflik, atau Perkara Pertanahan untuk mendapatkan penanganan 
penyelesaian sesuai dengan ketentuan peraturan perundang-undangan dan/atau kebijakan pertanahan.

Dalam menyelesaikan sengketa, Kepala Kantor Wilayah BPN atau Menteri akan menerbitkan:

a) Keputusan Pembatalan Hak Atas Tanah, yaitu pembatalan terhadap hak atas tanah, tanda bukti hak dan daftar umum lainnya yang berkaitan dengan hak tersebut

b) Keputusan Pembatalan Sertifikat, yaitu pembatalan terhadap tanda bukti hak dan daftar umum lainnya yang berkaitan dengan hak tersebut, dan bukan pembatalan terhadap hak atas tanahnya.

c) Keputusan Perubahan Data pada Sertifikat, Surat Ukur, Buku Tanah dan/atau Daftar Umum lainnya; atau

d) Surat Pemberitahuan bahwa tidak terdapat kesalahan administrasi.

Dalam hal di atas satu bidang tanah terdapat tumpang tindih sertifikat hak atas tanah, Menteri atau Kepala Kantor Wilayah BPN sesuai kewenangannya menerbitkan Keputusan pembatalan sertifikat yang tumpang tindih, sehingga di atas bidang tanah tersebut hanya ada 1 (satu) sertifikat hak atas tanah yang sah.

Keputusan penyelesaian Sengketa atau Konflik dilaksanakan oleh Kepala Kantor Pertanahan. Dalam hal Keputusan berupa Pembatalan Hak Atas Tanah, Pembatalan Sertifikat atau Perubahan Data, Kepala Kantor Pertanahan memerintahkan pejabat yang berwenang untuk memberitahukan kepada para pihak agar menyerahkan sertifikat hak atas tanah dan/atau pihak lain yang terkait dalam jangka waktu paling lama 5 (lima) hari kerja.

Setelah pemberitahuan atau pengumuman, Kepala Kantor Pertanahan memerintahkan pejabat yang berwenang menindaklanjuti keputusan sebagai berikut:

1) Dalam hal Keputusan berupa pembatalan hak atas tanah: pejabat yang berwenang melakukan pencatatan mengenai hapusnya keputusan pemberian hak, sertifikat, surat ukur, buku tanah dan Daftar Umum lainnya, pada Sertifikat hak atas tanah, Buku Tanah dan Daftar Umum lainnya.

2) Dalam hal Keputusan berupa pembatalan sertifikat: pejabat yang berwenang melakukan pencatatan mengenai hapusnya hak pada Sertifikat, Buku Tanah dan Daftar Umum lainnya.

3) Dalam hal Keputusan berupa perubahan data: pejabat yang berwenang melakukan perbaikan pada Sertifikat, Surat Ukur, Buku Tanah atau Daftar Umum lainnya. Setelah dilakukan perbaikan, sertifikat diberikan kembali kepada pemegang hak atau diterbitkan sertifikat pengganti.

Dengan demikian Setiap orang berkesempatan untuk memiliki hak atas tanah di Indonesia, namun dengan memperhatikan Asas Kenasionalan pada Pasal 1 ayat (1), ayat (2) dan ayat (3) Undang-Undang Nomor 5 Tahun 1960 tentang Peraturan Dasar Pokok-Pokok Agraria (untuk selanjutnya disebut UUPA) dan Asas Hanya Warga Negara Indonesia yang Mempunyai Hak Milik Atas Tanah pada Pasal 9 ayat (2) dan Pasal 21 ayat (1) UUPA, maka orang dengan kewarganegaraan selain Indonesia atau orang asing memiliki batasan-batasan atas hak atas tanah yang dapat dimiliki di Indonesia. Adapun hak-hak atas tanah yang dapat dimiliki oleh orang asing hanya terbatas pada hak pakai dan juga hak sewa yang keduanya memiliki batasan jangka waktu yang harus diperhatikan. Hak atas tanah atau yang menurut Urip Santoso disebut sebagai hak penguasaan atas tanah, merupakan "hak yang berisi 
serangkaian wewenang, kewajiban dan/atau larangan bagi pemegang haknya untuk berbuat sesuatu mengenai tanah yang dihaki (Santoso, 2017: 10)"

Persengketaan yang muncul diselesaikannya melalui pengadilan umum dan pengadilan tata usaha negara dan namun pada kenyatannya penyelasaian yang dilakukan oleh peradilan sebagian besar diselesaikan dengan hasil yang kurang memuaskan, diantaranya ada perbedaan putusan yang dilakukan oleh pengadilan umum dan Pengadilan Tata Usaha Negara untuk kasus sengketa atas tanah yang sama, dalam sebagian besar kasus, keputusan yang telah memiliki kekuatan hukum tetap (inkracht van gewijsde) pun tidak dapat dieksekusi. Penyebabnya, untuk sengketa tanah yang sama bisa terdapat beberapa putusan lain yang juga telah berkekuatan hukum tetap. Dengan demikian keputusan-keputusan itu saling bertentangan, dan bisa terjadi akibat tidak adanya data yang akurat di pengadilan atau penegak hukum. Kenyataan tersebut, direkomendasikan untuk dibentuknya adanya regulasi peraturan perundang-undangan khusus yang mengatur tentang persoalanpersoalan sengketa atas tanah, dengan terbentuknya lembaga independen yang menangani penyelesaian sengketa tanah diperlukan juga rekonstruksi perilaku hakim yang berwenang untuk menangani permasalahan sengketa yang ditanganinya berupa melakukan rekonstruksi tentang perilaku Birokrasi tersebut terjadi secara berulang-ulang hingga semakin menambah panjang daftar permasalahan dari berbagai kasus yang berawal dari sengketa tanah (agraria) di Indonesia (Ningrum, 2014: 221).

\section{Kesimpulan}

Hak Pakai hanya dapat dialihkan kepada pihak lain dengan izin pejabat yang berwenang. Namun, apabila terdapat tanah yang merupakan tanah hak milik, maka pengalihan Hak Pakai kepada pihak lain hanya dimungkinkan apabila dinyatakan secara tegas dalam perjanjian. Jadi, apabila dalam suatu kejadian pemegang Hak Pakai kehilangan persyaratannya atas hak tersebut, maka pihak tersebut akan kehilangan haknya dan wajib mengalihkannya kepada pihak lain atau Hak Pakai tersebut dihapuskan. Badan Pertanahan Nasional bisa melakukan penyelesaian sengketa dengan dua cara, cara yang pertama yaitu dengan menjalankan amar putusan pangadilan yang telah memperoleh kekuatan hukum tetap bahwa amar putusan pengadilan yang telah memperoleh kekuatan hukum tetap, yang berkaitan dengan penerbitan, peralihan dan/atau pembatalan hak atas tanah. Cara yang kedua adalah, Badan Pertanahan Nasional (BPN) melakukan pembatalan pemberian hak tanpa adannya putusan dari pengadilan.

\section{Daftar Referensi}

Ayu, G. D. (2010). Pemberian Akta Hak Pakai Atas Tanah Hak Milik Sebagai Alternatif Bagi Warga Negara Asing Untuk Dapat Memiliki Rumah Tinggal Di Indonesia Dalam Menunjang Kepentingan Investasi. Universitas Indonesia.

Hallauw, D. K., Matuankotta, J. K., \& Uktolseja, N. (2020). Analisis Hukum Surat Pelepasan Hak Atas Tanah Adat (Dati) Di Kota Ambon. SASI, 26(1), 111-118. https:// doi.org/10.47268/sasi.v26i1.256

Hamzah, A., Suandra, I. W., \& Manalu, B. A. (2006). Dasar-Dasar Hukum Perumahan. Rineka Cipta.

Hetharie, Y. (2019). Perjanjian Nominee sebagai Sarana Penguasaan Hak Milik atas Tanah oleh Warga Negara Asing (WNA) Menurut Kitab Undang-Undang Hukum Perdata. 
SASI, 25(1), 27-38. https:/ / doi.org/10.47268/ sasi.v25i1.147

Kotalewala, F., Laturette, A. I., \& Uktolseja, N. (2020). Penyelesaian Sengketa dalam Pengadaan Tanah Bagi Pembangunan Jalan untuk Kepentingan Umum. SASI, 26(3), 415-433. https:/ / doi.org/10.47268/sasi.v26i3.397

Laturette, A. I. (2021). Penyelesaian Sengketa Hak Ulayat pada Kawasan Hutan. SASI, 27(1), 102-112. https:/ / doi.org/10.47268/sasi.v27i1.504

Lawalata, S. H., Matuankotta, J. K., \& Uktolseja, N. (2021). Konsinyasi/Penitipan Uang Sebagai Bentuk Ganti Rugi Atas Pengalihan Hak Tanah. PAMALI: Pattimura MagisterLaw Review, 1(1), 16-29. https://fhukum.unpatti.ac.id/jurnal/pamali/article/view/481

Marzuki, P. M. (2016). Penelitian Hukum,. Kencana. https:/ / doi.org/340.072

Murad, R. (1991). Penyelesaian Sengketa Hukum Atas Tanah. Alumni.

Ningrum, H. R. S. (2014). Analisis Hukum Sistem Penyelesaian Sengketa Atas Tanah Berbasis Keadilan. Jurnal Pembaharuan Hukum, 1(2), 219-227. https:// doi.org/10.26532/jph.v1i2.1481

Rooy, O. R. de, Salmon, H., \& Nendissa, R. H. (2021). Hak Atas Tanah Pada Kawasan Konservasi. PAMALI: Pattimura MagisterLaw Review, 1(1), 40-54. https:// fhukum.unpatti.ac.id/jurnal/pamali/article/view/483

Saija, R., Letsoin, F. X. V. R., Akyuwen, R. J., \& Radjawane, P. (2020). Status Kepemilikan Hak Atas Tanah Adat Marga dalam Kebijakan Penataan Aset Reforma Agraria Di Kabupaten Maluku Tenggara. SASI, 26(1), 99-110. https:// doi.org/10.47268/sasi.v26i1.246

Santoso, U. (2017). Hukum Agraria : Kajian Komprehensif. Kencana Prenada Media Group.

Sarjita. (2008). Teknik dan Strategi Penyelesaian Sengketa Pertanahan. Tugu Jogja Pustaka.

Subekti. (2008). Hukum Perjanjian. Intermasa, Jakarta.

Syaifuddin, M. (2016). Hukum Kontrak: Memahami Kontrak Dalam Perspektif Filsafat, Teori, Dogmatik, dan Praktik hukum (Seri Pengayaan Hukum Perikatan). Mandar Maju. 